\title{
Structural innovations: towards a unified perspective?
}

\author{
Jeremy Howells and Jakob Edller
}

\begin{abstract}
This article argues that the intervention to generate structural innovations and with it the structural interaction between organisation actors can be understood as attempts to tackle system failures in innovation systems, mainly as regards networking and actor capabilities. However, these interventions are challenging, they often rest on simplistic assumptions on interaction and networking needs and potentially generate dysfunctional systemic effects. These challenges are discussed using illustrations of structural innovations to improve industry-academic collaborations in the UK and Germany. The article then concludes with a conceptual and policy discussion of opportunities, challenges and unintended consequences of deliberate structural innovation and intervention in structural interaction.
\end{abstract}

$\mathrm{T}$ IHE AIM OF THIS ARTICLE is to explore the nature and development of structural innovations in innovation systems, in particular around industry-academic collaboration, and how governance and performance issues affect such emergent processes. Structural innovations in this context cover new, innovative forms of institutional, governance and configurational relationships within an innovation system. It is argued here that these structural innovations are important in defining and re-setting the in-novation landscape and ecosystem and provide important frameworks for firm growth and performance. Although the systems of innovation literature has discussed elements of what are defined as structural innovations this has not been done

At the time of writing, both authors were at the Manchester Institute of Innovation Research, Manchester Business School, University of Manchester, Harold Hankins Building, Manchester M13 9PL, UK. Professor Jeremy Howells is now Dean of Faculty of Business and Law at the University of Southampton, Building 4/4037, Southampton SO17 1BJ, UK; Email: j.howells@soton.ac.uk; Tel: +44 238059 6843. Professor Jakob Edler is Professor of Innovation Policy and Strategy at MIoIR; Email: Jakob.Edler@mbs.ac.uk.

Significant parts of this article arise out of research funded by the UK Economic and Social Research Council (Grant Number ESRC RES-171-25-0038) as part of the Impact of Higher Education Institutions in Regional Economies Programme. Thanks also go to the anonymous reviewers for their very helpful comments on earlier drafts of this article. in a unified or coherent way. This article seeks to define and articulate more clearly what we mean as structural innovations and systematically analyse them. The article then seeks to explore and 'test' these frameworks by exploring such arrangements more specifically within the context of industryacademic collaboration.

The article has three main elements. The first is to review the emerging literature on structural innovations and, within this, to clarify the concept of structural interaction and how it relates to architectural and organisational innovation patterns and processes. As such, the article will seek to review, define and analyse structural innovations within an innovation systems context. The second element then investigates the concept of actors, actor networks and structural holes as a background to understand structural innovations and interactions. The third element is the discussion of governance challenges and performance effects when it comes to policy-induced structural innovations and deliberate changes in structural interaction.

These challenges are discussed using illustrations of structural innovations to improve industryacademic collaborations in the UK and Germany. The two countries offer important contrasts both in terms of where they are located on the 'liberal market' versus 'coordinated market' spectrum (Hall and Soskice, 2001) and as outlined provide contrasting policy approaches within the field of higher education and industry-academic collaboration. The 
Professor Jeremy Howells is Dean of the Faculty of Business and Law at the University of Southampton. He previously held the Eddie Davies Chair of Entrepreneurship and Innovation at the University of Manchester and was the previous Executive Director of the Manchester Institute of Innovation Research and Head of the Strategy Division, at Manchester Business School. His research interests cover innovation, knowledge transfer and research and development. $\mathrm{He}$ is also Executive Director of the IDEAS partnership based at Daresbury and Editor of R\&D Management as well as being on the editorial board of a number of other leading innovation journals.

Professor Jakob Edler is Executive Director of the Manchester Institute of Innovation Research at the Manchester Business School, University of Manchester, which is one of the largest and globally leading university institutes in its field <research.mbs.ac.uk/innovation/>. Jakob's main research areas are innovation and science policy and modes of governance, governance dynamics in innovation systems, demand-oriented innovation policy and public procurement, comparative research on public and private internationalisation strategies in science and technology, knowledge supply and technology transfer; industrial knowledge management and patent strategies. Jakob has studied at the University of Mannheim, Germany, and Dartmouth College, New Hampshire, USA, and holds a PhD in political science, an MA in political science/economic history and a Dipl. Kaufmann (MA business administration). Prior to his position at MlolR, he worked at the Fraunhofer Institute for Systems and Innovation Research, Karlsruhe, Germany. Jakob is member of the executive committee of the innovation policy network EU-SPRI.

article then concludes with a conceptual and policy discussion of opportunities, challenges and unintended consequences of deliberate structural innovation and intervention in structural interaction.

\section{Structural innovations and systems of innovation}

\section{Context}

Although there has been much discussion about what constitutes an innovation system there are a number of elements of the system of innovation approach that have received less attention. One of these is what might be termed as the structure and configuration of how an innovation system is "put together' and functions and, more especially within an evolutionary context, how innovation in these functional and configurational arrangements occurs and what they represent (Metcalfe, 1995). At a broad level this focus may be described as trying to conceptualise and describe the changing dynamics of the innovation landscape.

However, much of the discussion around the field of institutional and governance relations within the context of innovation systems has been in relation to their role of blocking innovation and change, that is, why change or innovation within the system did not occur, rather than around why innovation did occur in terms of their role in effecting change and new paths of economic growth. This may in part reflect the influence of North's $(1987,1991,1992,1993)$ work on institutions which emphasised their role as barriers to change and providing lock-in and stasis to development in economic systems. It also, quite rightly, reflects the need to identify the policy justification reasons for intervening in changing the innovation.

Carlsson and Jacobsson (1997), Smith (1997), Breschi and Malerba (1997), Johnson and Gregersen (1994), and Edquist (1997) have all reviewed, in various ways, issues associated with policy intervention around these issues of system failures. System failures have been variously categorised (see, for example, Carlsson and Jacobsson, 1997; Edquist, 1997; Smith, 1999; Woolthuis et al., 2005) but cover five main types: infrastructural failures; network failures; institutional failures; capability and organisational failures; and adjustment failures. Some of these system failures relate to what might be termed structural innovation failures associated with structural interaction which we define as the institutionalised exchange and cooperation of organisational actors. These structural interaction issues, however, can in turn relate to architectural and organisational innovation patterns and processes - that is, collaborative and network links within an innovation system for the purpose of generating innovation - as well as governance and institutional frameworks associated with such links. These issues will be explored further, after first seeking to clarify the concept of structural innovations.

\section{Structural innovations: a definition and framework}

Structural innovations have been defined here as covering new, innovative forms of institutional, governance and configurational relationships within an innovation system. More specifically, they relate to the following main elements:

1. New institutional frameworks These affect innovative activity within a system. This includes, for example, the formation of new intellectual property rights (IPR) regimes and routines or new mechanisms and practices associated with knowledge transfer and exchange. This, in turn, influences other aspects of structural innovation, such as new configurational relationships.

2. New governance arrangements These cover wider inter-institutional frameworks which help shape institutional arrangements (see 1. above) and determine the capacity of governments and other bodies to effectively manage its resources and policies (see Frederickson and Smith, 2003; United Nations Economic and Social Council, 2006) and are associated with key contractual and other governance links (Morgan, 2004) and new modes of governance (Yoshikawa et al., 2007; Perry, 2007). Kitschelt's (1991) important work on governance structures and how they contribute to, or hinder, successful patterns of industry development is especially relevant here. 
3. New actors or organisational forms This involves one pre-condition for novel forms of structural interaction through the emergence of new actor (organisational) types or sets (Luukkonen, 2005; Howells, 2006) or organisational arrangements, such as new project-based organisational forms (Nightingale, 2010) within a system. Thus, actor structures can be associated with specialisation and niche development with different types of actors (firms) focusing on different innovation tasks within innovation networks or value chains (Geels and Schot, 2007), whereby changes in actors (and their functions) and organisational forms imply changes in their interaction.

4. New configurational relationships These involve new arrangements and configurations associated with new networks and open innovation relationships (Powell et al., 1996). This does not just involve more collaborative links associated with innovation, but also the way they are organised and controlled (Pennings and Harianto, 1992). Studies have shown that how firms organise and structure their networks can influence performance (see, for example, Zaheer and Bell, 2005). This has turned attention toward the potential of network patterns to influence the performance of aggregate groups of firms in some way. Some of these new relationships have a clear overlap with new organisational forms and are noted below.

\section{Structural innovations and structural interaction}

The concept of structural innovation and interac-tion involves the creation and formation of new organisations and their (network) links, and architectural and organisational innovation patterns and processes. This has links with both the more micro focus of the notion of architectural innovations (Henderson and Clark, 1990) and modularisation and relationships of components within and between individual innovations and the larger-scale concept of innovation landscapes which represent the portion of external task environment of firms and organisations in relation to innovation processes and factors (see Markard and Truffer, 2008).

The evolution of innovation systems can be conceptualised as a co-evolution of supply and demand practice, on the one hand, and structure to support those practices on the other hand. The generation and diffusion of innovation is increasingly associated with architectural and open innovation modes. Functionally speaking, these changing modes co-evolve with changing functions of existing firms and organisations or the emergence of new firms and organisations in the innovation system. This necessitates and enables new forms of relationships. With changes in innovation patterns the external needs of firms change as well as the opportunity structures for scientific and intermediary organisations. Structural innovations are therefore the ensemble of organisational and relational changes and adaptations in a system that evolves around new forms or modes of innovation. In turn, structural interactions help frame those relations between organisational actors that are essential to enable the exchange and cooperation functionally demanded in the new modes of innovations.

\section{Closing gaps: establishing new actors and links}

A key structural feature, that focuses on structur-al interaction and where novelty and innovation can occur, relates to two key areas: first, network density, configuration and links within an innovation system; and, second, to the lack of actors in terms of quantity or type.

However, the view that better, more and different types of links and actors is better for an innovation system and the performance of firms and other organisations within it individually and collectively is not as straightforward as it seems. Each of these issues and contrasting views are discussed below.

\section{More links? Networks and structural holes}

Most studies of national and regional innovation systems have assumed that the more links and the denser the network ties between firms and other organisations the better in terms of both individual firm and actor performance as well as in terms of the system overall in such factors as resilience and diversity. Thus, intensive cooperation between actors can be very productive as a source of synergy, complementary knowhow, creative problem-solving and capacity-sharing (Woolthuis et al., 2005; Contractor and Lorange, 1988). On a more lo-calised level, this can be seen in terms of the cluster development and evolution and the positive performance of firms residing within those clusters (Bapista and Swann, 1998; Bell, 2005). Effective innovation is increasingly the result of close interaction between complementary technologies and actors. When the connectivity among these elements is poor, key cycles of learning and innovation may be prevented.

However, there has been a countervailing view about the risks of high-intensity network relations. These centre on traditional 'lock-in' failures and fears, but again can be seen on two levels: on an aggregate level and more individual terms in relation to the organisation itself. In relation to aggregate terms a number of studies have outlined the risk of network lock-in associated with high levels of functional interdependence (Håkansson and Johanson, 1988; see also Håkansson and Snehota, 2006). Thus, there can be considerable risks associated with strong cooperative relationships among an established group of actors. This relates to the wider concept of the lack of 'weak ties' and the danger of over-embeddedness expounded by Granovetter $(1983 ; 1985)$ and linked to the concept of social liability (Leenders and Gabbay, 1999). 
The "strength of weak ties" is based on the proposition that relative strangers offer an advantage over close acquaintances in obtaining useful information and knowledge and this has been expanded to cover organisations and their network relationships. Too strongly developed, inwardlooking clusters and networks can mean that they can become too isolated to wider radical and disruptive developments that can then threaten their long-term trajectory (Sunley, 1992). 'Weak ties' form important 'bridges' to outsiders who are external to the main network or cluster coming from different sectoral, technological, national or cultural backgrounds (see Jack, 2005). It is because of their relative distance from the 'inner circle' that such outlier contacts have not become a part of the main 'group think' as described above.

Both Granovetter (1983) and Burt (1992) emphasise the importance of these relationships because these form the weak links to new knowledge and impulses or span the structural holes (Burt, 1997) of knowledge that the individual firm lacks (Tsai, 2002). As such, they stress the need for a broad and diverse portfolio of external linkages with external parties to keep up to date with new developments and monitor developments in new knowledge, technology and skills (Goyal and Vega-Redondo, 2007). More specifically, Carlsson and Jacobsson (1997) describe the situation of strong network failure as one in which individual actors are guided by other network actors in the wrong direction and consequently fail to supply each other with the required knowledge. This is caused by a lack of information exchanges with actors who perform a bridging role, that is, who tap into new knowledge and question existing routines. This may potentially block renewal from outside.

Successful networks (hot spots) may then well develop into unsuccessful ones (blind spots) due to their ignorance of relevant developments outside (Pouder and St John, 1996), such as the Lancashire textile industry in the inter-war period (Sunley, 1992). A firm's 'network position' can therefore be vital for its long-term survival, growth and development (Håkansson and Johanson, 1988; Anderson et al., 1994), influencing, in turn, its wider bargaining position within its task environment (Yuchtman and Seashore, 1967) and the ultimate success of the firm.

The effect of network ties and collaborative links, particularly their pattern or structure, on firm performance (McEvily and Zaheer, 1999; Zaheer and Bell, 2005; Rowley and Baum, 2008) is important here. Firms occupying the favoured network position of 'bridging' structural holes (i.e. the gaps between firms otherwise disconnected in the network) are likely to perform better because of their superior access to information and knowledge (Burt, 1992, McEvily and Zaheer, 1999; Gulan et al., 2009). Because certain types of knowledge are obtained through firm interaction (Zaheer and Bell, 2005),

\section{Innovation systems with structural holes provide significant opportunities for firms that can bridge these holes, although a system with such holes may be considered sub-optimal in terms of the opportunities it provides organisations in aggregate}

actors who bridge structural holes will be able to develop new combinatorial capabilities and better perspectives on the threats and opportunities posed by the changing task environment of the firm and the system within which it resides (for example, the role of innovation intermediaries in this context) (Howells, 2006).

Innovation systems with structural holes, therefore, provide significant opportunities for firms that can bridge these holes, although a system with such holes may be considered sub-optimal in terms of the opportunities it provides firms and organisations in aggregate. Firms that bridge structural holes may be expected to benefit from bridging structural holes independent of the innovation-related benefits of structure. For example, those firms will be well positioned to learn efficiently and quickly about, and develop novel responses to, industry trends. As such, superior network position within the context of exchange relationships (Levine and White, 1961) can exert a positive influence on firm performance, including enhanced efficiency, better access to resources (including information or knowledge), and better identification of and responses to emerging threats and opportunities. Because maintaining ties to many other actors is costly (Burt, 1997; Gnyawali and Madhavan, 2001), it is important that firms, while benefiting from such functional links, constantly manage their relations and eliminate redundant ties.

It is in this context that in bridging structural holes new firms also generate innovation-related benefits. They are in principle able to access resources from parts of their contact profile that other firms cannot access (Tsai, 2002). Equally, bridging positions can provide better listening posts to changes in innovation dynamics or changes in the wider innovation system, and are better to explore the experience and trustworthiness of possible partners and collaborators (Harris et al., 2000; Rowley et al., 2000).

However, Ahuja $(2000 \mathrm{a}, \mathrm{b})$ tested the extent to which a firm's innovative output was influenced by the structural holes it spanned, and found a negative relationship. From that study spanning structural holes actually resulted in poorer innovation 
performance (according to patent generation). Collaborative relationships seemed to benefit more from trust engendered by dense networks rather than information diversity garnered through structural holes (Ahuja, 2000b).

It appears, therefore, that firms that already possess high levels of innovative capability and are in a good position to bridge structural holes in their network may be able to access novel, diverse, and unique information and more successfully recombine, transform, and utilise the information to generate valuable innovation (Woolthuis et al., 2005). Tiwana (2008), studying alliances in a major US services conglomerate, has a more nuanced finding and combines strong and weak ties, emphasising the need for bridging ties to provide access to diverse, structural hole-spanning perspectives and capabilities, but also to possess strong 'introspective' ties required to un-derpin the commercialisation process.

\section{More actors: too many, too few?}

Studies on system failures have identified all kinds of dimensions, but neglect the importance of adequate actors as essential parts of the system. Arnold (2004), with his focus on actor capabilities and adequacy of public organisations suggests a possible entry point to better grasp the importance of actors. However, we can expand on this and postulate that if essential organisations are lacking in the system, system failure occurs on the 'actor's side'. It has been noted that 'missing actors' should not necessarily be regarded as systemic failures on the 'rules' side' although the absence of certain actors can cause systemic failure (Edquist, 1997). For example, if regulatory bodies are absent, firms will miss certain kinds of regulations and this can have implications for them, say, in safeguarding their IPR in the innovation process. Other examples of missing actors might be certain types of innovation intermediaries, venture capitalists, insufficient lack of lead users, specific types of research institutes oriented to knowledge transfer and exchange.

Thus, a frequent and reoccurring issue in the UK is whether the UK should develop organisations which are similar to the Fraunhofer institutes in Germany to support and augment universities' activities in knowledge exchange (Hauser, 2010). However, whether the absence of certain actors leads to compensation effects among the existing set of actors, whether the range and diversity of the actor set affects future actor/organisational evolution (Howells, 2010) or the nature of unintended effects from the emergence of new actors on the networking behaviour of incumbents in an innovation system are unresolved issues.

The final part of this article will discuss the meaning of actor sets, structural innovation and structural interaction more specifically within the context of knowledge transfer and exchange, specifically within the industry-academic links.

\section{Structural interaction and innovation: the case of knowledge transfer and industry- academic frameworks}

The higher education system offers an interesting sub-system to examine because it intersects with a number of key research, knowledge-exchange and education-system communities (see Mowery and Sampat, 2005). It is also a sub-system that has undergone a great deal of dynamic change driven by changing policy rationales and mechanisms. For the United Kingdom (UK), Halsey (1995: 302) has gone as far as noting:

British higher education has undergone a more profound reorientation than any other system in the industrialised world.

In this respect, therefore, one might expect that structural innovations would have been more likely to emerge in recent years. However, comparing the UK with Germany allows us to view such innovative changes within a wider context. The two countries offer important contrasts both in terms of where they are located on the 'liberal market' (UK) versus 'coordinated market' (Germany) spectrum (Hall and Soskice, 2001: 8-9), but also in the often opposing directions they take in relation to industrial, innovation and higher education policy (Soskice, 1997).

\section{New institutional frameworks}

Incentive structures have been experimented with in various parts of Europe to encourage engagement and technology transfer between academia and industry, although success of these structures and incentives have tended to focus on easy-to-measure outcomes, such as licensing or patenting activity (Link and Siegel, 2005; Siegel et al., 2003) and in fairly standard organisational forms (Bray and Lee, 2000).

The main developments in the UK have been around creating internal incentive structures to encourage university staff to engage and interact with industry and to facilitate entrepreneurial spin-offs. They have also been directed toward universities in the UK seeking to 'professionalise' their knowledge transfer, aiming to improve their routines and practices around engagement with industry and other key stakeholders. Examples of these different schemes have been outlined over recent years (Howells et al., 1998; Charles and Conway, 2001) and have been further refined and developed by universities and higher education institutions. Many of these developments have coalesced around the establishment of technology transfer organisations (TTOs) within British universities, that have sought to move beyond the early industrial liaison offices (ILOs) of the early 1970s, although some argue that these new types of TTO actually represent new internal actor types (see Mina et al., 2009). 
By contrast, Germany has taken a very different approach by abolishing the law that gave exclusive right to professors to own their patents and licence them exclusively, ${ }^{2}$ now ownership passes to the universities with professors having to notify their universities (similar to practices that occur in firms). This has necessitated new bridging institutions, such as the Patent Exploitation Agency, to help manage patents and licence them out to industry. Although Schmoch (2008) expects a growth of patenting with the Patent Exploitation Agency as a cornerstone of government policy (over time a specialised licensing institution might improve licence income) direct links between professors and industry might diminish as incentives to patent decrease. Recent statistics seem to indicate the diminution of links (Polt et al., 2009: 16), although the long-term outcome of such changes will take longer to discern. Certainly UK evidence suggests that royalty income going directly to the inventor is positively related to the generation of licensing income and its growth (Lockett and Wright, 2005).

\section{New governance models}

New governance arrangements within the higher education and knowledge transfer realm have tended to encompass changes in funding regimes, but also changes in regulation that allow university staff to engage with knowledge transfer with industry or hold executive functions with spin-out companies. Studies that have tried to chart and assess more novel incentive structures or management routines and practices around knowledge exchange have been limited up until now. Identifying what works and what does not work has been centred on the interpretation and learning-by-doing of individual universities and organisations rather than a more general inter-organisational sharing of such good-practice routines.

One obvious central governance instrument in the UK that influences interaction is the Research Assessment Exercise (RAE) and its replacement, the Research Excellence Framework (REF) which rewards (or punishes) interaction with companies in terms of impact and esteem of the individual. While the RAE and REF were intended to reward excellence and relevance, they can also generate disincentives to cooperate among academics in general (due to the competitive nature of the exercise) (Elton, 2000). Moreover, inter-disciplinary and application-oriented research collaboration may be discouraged (Nowotny et al., 2003: 183-184) as both forms tend to be disadvantaged in the overriding imperative to publish in high-ranking, discipline-specific journals.

In Germany, the framework conditions for scienceindustry relations have traditionally been comparatively good, and the scope and scale of ties exceptional in international comparison (Rammer, 2006). This is mainly due to the functionally differentiated public research system, a high share of research intensive industry and export-oriented small and medium-sized enterprises (SMEs) engaged in contract research (Grupp et al., 2002; Schmoch, 2008), but it has also been enabled, and this is crucial in our context, through the introduction of a specific form of governance in the early 1980s which set cooperation between firms and public research as a pre-condition for receiving $R \& D$ subsidies in most federal programmes (so-called Verbund-forschung; Edler, 2000; Schmoch, 2008).

\section{New actors or organisational forms}

Within the UK there has been an ongoing debate as to whether the UK should develop organisations which are similar to the Fraunhofer institutes in Germany to support and augment universities' activities in knowledge exchange. The Faraday Partnerships, introduced in 1997, follow this pattern with some 24 partnerships being set up and in operation by 2005 (Hughes, 2007: 85). However, soon after this they were dissolved or transformed into looser network structures: knowledge transfer networks (KTNs). In early 2010 the concept was under further consideration by the then Labour Government, and a specific report on this issue recommended the "provision of a business-focused capability that bridges research and technology commercialisation' in the form of technology and innovation centres (Hauser, 2010: 3). ${ }^{3}$

The issue of whether the UK needs to develop a new set of publicly supported intermediary innovation actors, performing a range of innovation-related functions (Howells, 2006) to act as a bridge between universities and industry, is one that has attracted discussion among a number of UK academics and policy-makers. Notably, Mina et al. (2009) note that although the vast majority of businesses in the UK, the USA and elsewhere cite themselves, customers and suppliers as their main sources of knowledge, hardly any use these alone as a sole source for new innovative ideas. Indeed, the next most frequent set of sources combined with business sector sources are intermediary organisations and structures (Cosh and Hughes, 2010).

The German example is a very different one. Germany has an exceptionally well-established and functionally differentiated system of extra-university research organisations, whereby different types of organisations have different kinds of bridging roles (Edler and Kuhlmann, 2008; Polt et al., 2009). ${ }^{4}$ Moreover, in contrast to all other OECD countries, Germany has neither diminished the relative weight of funding for extra-university funding, nor created major new research actors. There has been a stable growth and adaptation of publicly co-funded research organisations outside the university system.

Situated at the two opposite sides of the spectrum, both the UK and Germany illustrate the potential deficiencies of bridging research organisations. For the 
UK, there is the notion that existing actors, through internal intermediary units (such as new forms of TTOs within universities), negate the need for the creation and support for these new actor forms. Indeed, the proposition here is that creating these new types of intermediary actors, or supporting existing ones, will slow down or, actually, halt universities developing new institutional forms and practices to collaborate and engage better with industry themselves. As such, the organisational evolution of a particular actor type may be hindered by the appearance of new actor forms in the innovation ecology of the system, as the transfer activity may be perceived as outsourced and pressures and opportunities for bridging adaptations within existing actors are perceived as being reduced.

Similarly, in Germany the existence of all kinds of functionally defined research and bridging organisations had led to the verdict that the system itself is compartmentalised. The existence of research and bridging organisations that are functionally differentiated has led to an inadequate capacity to create new kinds of linkages, especially between those bridging organisations themselves (Brook et al., 1999). The establishment of the new Patent Exploitation Agency, noted above, to manage patents from universities and licence them out to industry is a further illustration of this process. While a study for the area of nanotechnology (Heinze and Kuhlmann, 2008) finds a persistence of compartmentalisation in this area, an international comparison of cooperation patterns more generally has found that in general the extrauniversity research organisations show a high level of cooperation, both between each other and with industry (Polt et al., 2009: 4-8).

Apparently, the German system with its functional differentiation of extra-university research organisations has coped well with the need for more interaction in general, but struggles with creating the necessary density of linkages in new and emerging sciences that draw on a diverse set of disciplines and need a close interaction of technology appliers and scientists such as biotechnology (see, for example, Kaiser and Prange, 2004: 404). Bridging organisations need to fit the context as set by the scientific or technology area, as the bridging actor model does not fit equally well in all areas. In those areas in which the application of a technology is very close to, and relying on, the science base, as in nano- or biotechnology, they may actually hamper functional linkages.

\section{Newly configured relationships}

The emergence of new types of institutional arrangement, new forms of governance structures and innovation actors will, by their nature, disrupt but also encourage new configurational arrangements within an innovation system. A key disruptive effect in the UK system was the move away from the twotier system of universities and polytechnics towards a single unitary system of universities in the early 1990s. To some extent this made the combined systems more open in terms of network interaction effects, although in other ways university networks remain constrained around their own fairly tight collaborative trajectories and communities of interaction (see Lynn et al., 1996). Perhaps the most significant structural innovation as regards configurational relationships has not been triggered by new actors, but by new needs to reach out for linkages. Thus, there is evidence of a move away from simple dyadic (one-to-one) relationships in research and knowledge exchange towards more complex and more widely populated collaborative arrangements (see Anderson et al., 1994).

Moreover, a study by Sytch et al. (2010: 36) suggests that even in the global computer industry more complex network patterns did not emerge until the early 1990s, before which network structures were largely characterised by single dyad relations. This confirmed earlier views that such dense and complex network relationships were, at best, slow to emerge without some support. The KTNs, noted above, have in a sense reflected the UK-wide networks set up from 2005 and funded by the Technology Strategy Board replacing more specific organisational constructs such as the Faraday Partnerships.

In recognition of this increasing network complexity, some UK universities have sought to set up network partnerships both as a way to provide a more complete, but simple 'one-stop shop' research and knowledge exchange service to firms (such as the IDEAS partnership at Daresbury ${ }^{5}$ ) but also to help act as orchestrators or moderators of these complex innovation networks. Certain specialist innovation intermediaries have also taken on this network development and 'orchestration' role, moving be-yond their simple knowledge clearing-house role for firms (within a wider context; see Balthasar et al., 2000). In the UK this has often been at a sectoral level, with organisations, such as PERA, taking an increasing role with firms and research organisations in its sector.

In Germany there has been an increasing drive towards encouraging regional cooperation between actors, both through federal or state-level policies (Polt et al., 2009: 107-111). While many of these programmes have been evaluated as successful in terms of regional clusters and regional spill-over effects, there are indications that they also have detrimental effects on broader interaction. It has been shown that the cooperation patterns in Germany are not particu-larly shaped by regional considerations, because firms with specific needs cooperate with specialised institutes no matter where they are located within the country (Polt et al., 2009: 110). Hence, encouraging intra-regional configurations may be counter-productive in a broader macro perspective and for the individual organisations in the long run, because it diverts interactive behaviour from the national to the regional level. 


\section{Encouraging intra-regional configurations may be counter- productive in a broader macro perspective and for the individual organisations in the long run, because it diverts interactive behaviour from the national to the regional level}

Table 1 summarises examples of the four-fold typology of structural innovations and provides examples from the context of higher education and industry-academic links with reference just to two countries, the UK and Germany. On this tentative level, the framework and typology of what is meant by structural innovation is validated although we must be aware of different national contexts and, importantly, how different actors and models emerge from this context. Thus, recent research by Palsson et al. (2009) suggests that not only differing national contexts will be important in how structural innovations interact with each other, but also the organisational responses to such interactions will lead to different evolutionary patterns.

\section{Conclusions}

This article has sought to outline and examine the role of structural innovations in redefining and framing the innovation landscape and ecosystem and to offer a new framework for explaining firm growth and performance. Structural innovations are essential in the further development of the structural interaction of actors in the innovation process. In presenting this analysis we have attempted more rigorously to define and classify what may be termed as a 'structural innovation' and set this within a more holistic, integrative framework, acknowledging the interlocking and dynamic nature of structural innovation. We have sought to explore and test the construct by examining such arrangements more specifically within the context of industry-academic collaboration across two contrasting national systems, the UK and Germany.
In particular we have argued there is a need for a more holistic conceptualisation of the roles of new actors, and of new institutional, governance and configurational relationships in systems of innovation. Most importantly, any intervention in the system that creates structural innovation, as defined here, has immediate implications for structural interaction associated with institutional capability, organisational and adjustment failures. However, to understand the meaning of structural innovation and indeed to actively introduce them as a policy framework, all four types of structural innovation must be considered together, as innovation in one dimension (for example, institutional framework) has consequences on other dimensions and actually may need to be accompanied by further adjustments.

The analysis of industry-academic (or scienceindustry) relations with which we illustrate the role of structural innovation is an issue that is poorly articulated in relation to identifying those features of the innovation system that need developing or repairing. Policy formulation that does not appropriately take into account 'framework' innovations and the consequent detailed nature of the system failure(s) it seeks to address or the unintended consequences the innovation has for structural interactions of all actors concerned is likely to 'miss the point'.

The examples presented above have been illustrative. The intention to create more patents and thus transfer more scientific knowledge to industry in the German change of ownership of patents and the responsibilities for patent management and licensing and the creation of new actors to support this has apparently slowed down patenting activities because incentives for professors have deteriorated. This structural innovation has sought to close a structural hole and encourage universities to intensify technology transfer to industry, but it did not take into account the adverse effects of incentive structure for key actors (the professors) and thus the effect has been questionable.

Equally, the structural innovation of new innovation units and organisations in the UK (such as the former Faraday Centres and emerging TTOs) established to close the alleged structural gap between science and industry could (at least in scienceintensive technological areas) lead to the adverse effect of losing close ties between university academics and industry. Thus by not adequately absorbing, processing and transferring knowledge to

Table 1. Examples of structural innovations from knowledge transfer and industry-academic structures

Type of structural innovation

1. New institutional frameworks

2. New governance models

3. New actors and organisational forms

4. New configurational arrangements

\section{UK examples}

Incentive structures

RAE/REF

TTOs; Faraday Partnerships

KTNs
German examples

Abolition in 2002 of Professoen-Privileg

Verbundforschung

Patentverwertungsagenturen (PVAs)

Cluster-building and support through federal and regional initiatives (1995 onwards) 
industry, such innovation centres could result in blocking the direct (often informal) structural interactions and adequate configurational framework needed for them to be effective. This is not to deny that these institutes may help cure innovation system failures in the UK, but the overall effects on the configurational relationships needs to be analysed and adequate incentives and rules created to link the new model with the old, more direct one.

Our analysis seeks to contribute to a broader and more thorough understanding of what are meant by structural innovations and their meaning for system performance. While policy-makers have now become more guarded in adopting 'one size fits all' policy interventions, it should be acknowledged that the true meaning of diversity and context adequacy of structural innovations to cure system failures can only become clear if one understands the broader (intended and unintended) effects on structural interaction and actor capabilities.

\section{Notes}

1. This interestingly has close ties in the innovation literature to the earlier notion of 'technological gatekeepers' (Allen et al., 1970; Taylor, 1975), although there is little or no crossreferencing between the two extant research fields.

2. Professoen-Privileg (professorial privilege) was abolished in 2002, so that professors within German universities are now, in principle, no different from employees of other employers (private and public) and thus the regular ownership of a patent is with the employer (the university) rather than the professor, whereby the professor will have guaranteed publication rights, non-commercial use of the invention and also some financial reward nevertheless. This strengthens the position of the universities.

3. See commentary on Hermann Hauser's review of UK innovation policy (Research Foresight, 18 February 2010).

4. In Germany, there are four large umbrella organisations of research institutes, ranging from a basic research excellencefocused organisation (Max Planck) to application-oriented institutes within the Fraunhofer Society or specific sector organisations (Schmoch, 2008).

5. IDEAS at Daresbury (Innovation, Design, Entre-preneurship and Science) is a novel collaboration of the business/management schools of three stakeholder universities, along with Lancaster University's Design Thinking and Innovation Laboratory, Imagination. The initiative is further supported by the Science and Technology Facilities Council, the Northwest Regional Development Agency and Daresbury SIC. The mission of IDEAS at Daresbury is to promote effective knowledge exchange at the interface of SMEs, large corporations, universities and strategic government funded science and will drive innovation into primarily high-tech micro businesses located within the DSIC network and related regional facilities. See <http:/iwww.daresburysic.co.uk/collaborative partnerships/ukcollaborations/ideas-at-daresbury>

\section{References}

Ahuja, G 2000a. Collaboration networks, structural holes, and innovation: a longitudinal study. Administrative Science Quarterly, 45(3), 425-455.

Ahuja, G 2000b. The duality of collaboration: inducements and opportunities in the formation of interfirm linkages. Strategic Management Journal, 21, 317-343.

Allen, T J, J M Piepmeier and S Cooney 1970. Technology transfer to developing countries: the international technological gatekeeper. Sloan School of Management Working Paper, No. 479-70, MIT, Cambridge, MA.

Anderson, J C, H Håkansson and J Johanson 1994. Dyadic business relationships within a business network context. Journal of Marketing, 58, 1-15.

Arnold, E 2004. Evaluation research and innovation policy: a systems world needs systems evaluations. Research Evaluation, 13(1), April, 3-17.

Balthasar, A, C Battig and B Wilhelm 2000. Developers: key actors of the innovation process. Technovation, 20(10), 523-538.

Bapista, R and P Swann 1998. Do firms in clusters innovate more? Research Policy, 27, 525-540.

Bell, G G 2005. Clusters, networks, and firm innovativeness. Strategic Management Journal, 26(3), 287-295.

Bray, M J and J N Lee 2000. University revenues from technology transfer: licensing fees v. equity positions. Journal of Business Venturing, 15, 385-392.

Breschi, S and F Malerba 1997. Sectoral innovation systems: technological regimes, Schumpeterian dynamics, and spatial boundaries perspective. In Systems of Innovation: Technologies, Institutions and Organisations, ed. C Edquist, pp. 130156. London: Pinter.

Brook, $\mathrm{R}$ et al. eds 1999. Forschungsförderung in Deutschland. Bericht der internationalen Kommission zur Systemevaluation der Deutschen Forschungsgemeinschaft und der Max-PlanckGesellschaft. Hanover: Volkswagen-Stiftung.

Burt, R S 1992. Structural Holes: the Social Structure of Competition. Cambridge, MA: Harvard University Press.

Burt, R S 1997. The contingent value of social capital. Administrative Science Quarterly, 42(2), 339-365.

Carlsson, B and S Jacobsson 1997. Diversity creation and technological systems: a technology perspective.' In Systems of Innovation: Technologies, Institutions and Organisations, ed. C Edquist, pp. 226-294. London: Pinter.

Charles, D and C Conway 2001. Final Report to the Higher Education Funding Council for England (HEFCE). Bristol: HEFCE.

Contractor, $\mathrm{F} \mathrm{J}$ and $\mathrm{P}$ Lorange 1988. Cooperative Strategies in International Business. MA: Lexington Books.

Cosh, A and A Hughes 2010. Never mind the quality feel the width: university-industry links and government financial support for innovation in small high-technology businesses in the UK and USA. Journal of Technology Transfer, 35, 66-91.

Edler, J 2000. Institutionalisierung europäischer Politik. Die Genese des Forschungsprogramms BRITE als reflexiver sozialer Prozeß (Institutionalisation of European Policy. The genesis of BRITE-EURAM as a social-reflexive process). Baden-Baden: Nomos.

Edler, $\mathrm{J}$ and S Kuhlmann 2008. Co-ordination within fragmentation: governance in knowledge policy in the German federal system. Science and Public Policy, 35, May, 265-276.

Edquist, D 1997. Systems of innovation approaches: their emergence and characteristics. In Systems of Innovation: Technologies, Institutions and Organisations, ed. D Edquist, pp. 1-33. London: Pinter.

Elton, L 2000. The UK Research Assessment Exercise: unintended consequences. Higher Education Quarterly, 54(3), July, 274-283.

Frederickson, H G and K B Smith 2003. The Public Administration Theory Primer. Boulder, CO: Westview Press.

Geels, F W and J Schot 2007. Typology of sociotechnical transition pathways. Research Policy, 36, 399-417.

Gnyawali, D R and R Madhavan 2001. Cooperative networks and competitive dynamics: a structural embeddedness perspective. Academy of Management Review, 26, 431-445.

Goyal, S and F Vega-Redondo 2007. Structural holes in social networks. Journal of Economic Theory, 137, 460-492.

Granovetter, M 1983. The strength of weak ties: a network theory revisited. Sociological Theory, 1, 201-233.

Granovetter, M 1985. Economic action and social structure: the problem of embeddedness. American Journal of Sociology, 91, 481-510.

Grupp, H, I Dominguez-Lacasa and M Friedrich-Nishio 2002. Das deutsche Innovations-system seit der Reichsgründung: Indikatoren einer nationalen Wissenschafts- und Technikgeschichte in unterschiedlichen Regierungs- und Gebietsstrukturen. Heidelberg: Physica-Verlag.

Gulan, R, D Lane and H Singh 2009. The nature of partnering and the gains from alliances. Strategic Management Journal, 30 , 1213-1233.

Häkansson, $\mathrm{H}$ and J Johanson 1988. Formal and informal cooperation strategies in international industrial networks. In Cooperative 
Strategies in International Business, eds $\mathrm{F} J$ Contractor and $\mathrm{P}$ Lorange, pp. 369-378. Lexington, MA: Lexington Books.

Håkansson, $\mathrm{H}$ and I Snehota 2006. No business is an island: the network concept of business strategy. Scandinavian Journal of Management, 22, 256-270.

Hall, P and D Soskice 2001. An introduction to varieties of capitalism. In Varieties of Capitalism: the Institutional Foundations of Comparative Advantage, eds P Hall and D Soskice, pp. 1-71. Oxford: Oxford University Press.

Halsey, A 1995. The Decline of Donnish Domination: the British Academic Professions in the Twentieth Century. Oxford: Clarendon Press.

Harris, L, A-M Coles and K Dickson 2000. Building innovation networks: issues of strategy and expertise. Technology Analysis and Strategic Management, 12, 229-241.

Hauser, $\mathrm{H}$ 2010. The Current and Future Role of Technology and Innovation Centres in the UK. Report for the Department for Business Innovation and Skills, London. Available at $<$ http://www.bis.gov.uk/assets/biscore/innovation/docs/10-843role-of-technology-innovation-centres-hauser-review>, last 7 August 2009.

Heinze, T and S Kuhlmann 2008. Across institutional boundaries? Research collaboration in German public sector nanoscience. Research Policy, 37, 888-899.

Henderson, R M and K B Clark 1990. Architectural innovation: the reconfiguration of existing product technologies and the failure of established firms. Administrative Science Quarterly, 35, 9-30.

Howells, J 2006. Intermediation and the role of intermediaries in innovation. Research Policy, 35, 715-728.

Howells, J 2010. The nature, role and type of actors within innovation systems. Mimeo. Manchester: Manchester Institute of Innovation Research.

Howells, J, M Nedeva and L Georghiou 1998. Industry-Academic Links in the UK. Final Report to the Higher Education Funding Council for England (HEFCE). Bristol: HEFCE.

Hughes, A 2007. University-industry links and UK science and innovation policy. In How Universities Promote Economic Growth, eds S Yusuf and K Nabeshima, pp. 71-90. Washington, DC: World Bank.

Jack, S 2005. The role, use and activation of strong and weak network ties: a qualitative analyses. Journal of Management Studies, 42, 1233-1258.

Johnson, B and B Gregersen 1994. Systems of innovation and economic integration. Journal of Industry Studies, 2, 1-18.

Kaiser, R and H Prange 2004. The reconfiguration of National Innovation Systems: the example of German biotechnology. Research Policy, 33, 395-408.

Kitschelt, F H 1991. Industrial governance structures, innovation strategies, and the case of Japan. International Organisation, $45,453-493$.

Leenders, R T and S M Gabbay eds 1999. Corporate Social Capital and Liability. Boston: Kluwer.

Levine, S and PE White 1961. Exchange as a conceptual framework for the study of interorganizational relationships. Administrative Science Quarterly, 6, 583-601.

Link, A and D S Siegel 2005. Generating science-based growth: an econometric analysis of the impact of organisational incentives on university-industry technology transfer. European Journal of Finance, 11, 169-181.

Lockett, A and M Wright 2005. Resources, capabilities, risk capital and the creation of university spin-out companies. Research Policy, 34, 1043-1057.

Luukkonen, T 2005. Variability in organisational forms in biotechnology firms. Research Policy, 34, 555-570.

Lynn, L H, N M Reddy and J D Aram 1996. Linking technology and institutions: the innovation community framework. Research Policy, 25, 91-106.

Markard, $\mathrm{J}$ and $\mathrm{B}$ Truffer 2008. Technological innovation systems and the multi-level perspective: towards an integrated framework. Research Policy, 37(4), 596-615.

McEvily, B and A Zaheer 1999. Bridging ties: a source of firm heterogeneity in competitive capabilities. Strategic Management Journal, 20, 1133-1156.

Metcalfe, J S 1995. Technology systems and technology policy in an evolutionary framework. Cambridge Journal of Economics, $19,25-46$

Mina, A, D Connell and A Hughes 2009. Models of technology development in intermediate research organisations. Centre for Business Research Working Paper No. 396. Centre for Business Research, University of Cambridge.
Morgan, K 2004. Sustainable regions: governance, innovation and scale. European Planning Studies, 12, 871-888.

Mowery, D C and B N Sampat 2005. Universities in national innovation systems. In The Oxford Handbook of Innovation, eds $\mathrm{J}$ Fagerberg, D C Mowery and R R Nelson, pp. 209-239. Oxford: Oxford University Press.

Nightingale, P 2010. Servant firms in the UK pharmaceutical industry: an overlooked project based organisational form. Mimeo. SPRU, University of Sussex.

North, D C 1987. Institutions, transaction costs and economic growth, Economic Inquiry, 25, 419-428.

North, D C 1991. Institutions, Institutional Change and Economic Performance. Cambridge: Cambridge University Press.

North, D C 1992. Institutions and economic theory. American Economist, 36(1), 3-6.

North, D C 1993. Towards a theory of institutional change. Economic Inquiry, 25, 419-428.

Nowotny, H, P Scott and M Gibbons 2003. 'Mode 2' revisited: the new production of knowledge. Minerva, 41(3), 179-194.

Pålsson, C M, B Göransson and C Brundenius 2009. Vitalizing the Swedish university system: implementation of the 'third mission'. Science and Public Policy, 36, March, 145-150.

Pennings, J M and F Harianto 1992. Technological networking and innovation implementation. Organisation Science, 3, 356-382.

Perry, B 2007. The multi-level governance of science policy in England. Regional Studies, 41, 1051-1067.

Polt, W, M Berger, P Boekholt, K Cremers, J Egeln, H Gassler, R Hofer and C Rammer 2009. Das deutsche Forschungs- und Innovationssystem. Ein internationaler Systemvergleich zur Rolle von Wissenschaft, Interaktionen und Governance für die technologische Leistungsfähigkeit. Studien zum deutschen Innovationssystem Nr. 11-2010. Wien/Brighton/Amsterdam/ Mannheim, Oktober.

Pouder, R and C St John 1996. Hot spots and blind spots: geographical clusters of firms and innovation. Academy of Management Review, 21, 1192-1225.

Powell, W W, K W Koput and L Smith-Doerr 1996. Interorganisational collaboration and the locus of innovation: networks of learning in biotechnology. Administrative Science Quarterly, $41,116-145$.

Rammer, C 2006. Trend in innovation policies: an international comparison. In National Systems of Innovation in Comparison: Structure and Performance Indicators for Knowledge Societies, eds U Schmoch, C Rammer and H Legler, pp. 265-286. Dordrecht: Springer.

Rowley, T J and J A C Baum 2008. The dynamics of network strategies and positions. Network Strategy: Advances in Strategic Management, 25, 641-671.

Rowley, T J, D Behrens and D Krackhardt 2000. Redundant governance structures: an analysis of structural and relational embeddedness in the steel and semiconductor industries. Strategic Management Journal, 21, 369-386.

Schmoch, U 2008. The role of universities in economic growth the German situation. Lund University. UniDev Discussion Paper Series Paper no. 1. University of Lund.

Siegel, D S, D Waldman and A Link 2003. Assessing the impact of organisational practices on the relative productivity of university technology transfer offices: an exploratory study. Research Policy, 32, 27-48.

Smith, K 1997. Economic infrastructures and innovation systems. In Systems of Innovation: Technologies, Institutions and Organisations, ed. D Edquist, pp. 86-106. London: Pinter.

Smith, K 1999. Innovation as a systemic phenomenon: rethinking the role of policy. In A New Economic Paradigm? InnovationBased Evolutionary Systems, eds K Bryant and A Wells, pp. 10-47. Canberra: Commonwealth of Australia, Department of Industry, Science and Resources, Science and Technology Policy Branch.

Soskice, D 1997. German technology policy, innovation, and national institutional frameworks. Industry and Innovation, 4, 75-96.

Sunley, P 1992. Marshallian industrial districts: the case of the Lancashire cotton industry in the inter-war years. Transactions Institute of British Geographers, N.S. 17, 306-320.

Sytch, M, A Tatarynowicz and R Gulati 2010. Where do bridging ties come from? Mimeo. Ross School of Business, University of Michigan.

Taylor, R L 1975. The technological gatekeeper. R\&D Management, 5, 239-242.

Tiwana, A 2008. Do bridging ties complement strong ties? An empirical examination of alliance ambidexterity. Strategic 
Management Journal, 29, 251-272.

Tsai, W 2002. Knowledge transfer in intraorganizational networks: effects of network position and absorptive capacity on business unit innovation. Academy of Management Journal, 44(5), 996-1004.

United Nations Economic and Social Council 2006. Definition of basic concepts and terminologies in governance and public administration. Note by the Secretariat of the Committee of Experts on Public Administration, 06-20194 (E). New York: United Nations.

Woolthuis, R K, M Lankhuizen and V Gilsing 2005. A systems failure framework for innovation policy design. Technovation, 25, 609-619.

Yoshikawa, T, L S Tsui-Auch and J McGuire 2007. Corporate governance reform as institutional innovation: the case of Japan. Organisation Science, 18, 973-988.

Yuchtman, E and S E Seashore 1967. A system resource approach to organisational effectiveness. American Sociological Review, 32(6), 891-903.

Zaheer, A and G G Bell 2005. Benefiting from network position: firm capabilities, structural holes, and performance. Strategic Management Journal, 26, 809-825. 


\section{Research Evaluation}

Introduction to a special issue on designing indicators for policy decisions: challenges, tensions and good practices

Benedetto Lepori (University of Lugano, Switzerland), Emanuela Reale (CerisCNR, Rome, Italy) and Robert Tijssen (CWTS, University of Leiden, The Netherlands)

Pages 3-5

\section{Indicator needs for the} internationalisation of science policies Jakob Edler and Kieron Flanagan (University of Manchester, UK)

Pages 7-17

\section{Evaluation of firm R\&D and} innovation support: new indicators and the ex-ante prediction of ex-post additionality

Bianca Potì and Giovanni Cerulli (CerisCNR, Rome, Italy)

Pages 19-29

Informed peer review and uninformed bibliometrics?

Jörg Neufeld and Markus von Ins (IFQ, Bonn, Germany)

Pages 31-46

New uses of the institutional databases of universities: indicators of research activity

Emanuela Reale (Ceris-CNR, Rome, Italy) et al

Pages 47-60

Evaluation of research in context: an approach and two cases

Stefan P L de Jong (Rathenau Instituut, The Hague, The Netherlands) et al Pages 61-72

Profiles and beyond: constructing consensus on measuring research output in communication sciences Carole Probst (University of Lugano, Switzerland) et al

Pages 73-88
This special issue collects six papers (out of 80 submissions) from the Science and Indicators Conference organized by the European Network of Indicators Designers (ENID) in March 2010 in Paris, France. They cover quite different aspects of design of indicators for policy decisions, ranging from internationalization policies in research (Edler and Flanagan, 2011), to indicators to support the evaluation processes of funding agencies (Potì and Cerulli, 2011; Neufeld and Von Ins, 2011), to the analysis of publication outputs of higher education institutions (Reale, De Filippo, Gomez, Lepori, Poti, Primeri, Probst and Sanz Casado, 2011) and, finally, to two papers dealing with the highly contested issue of indicators to measure research output in social sciences and humanities (De Jong, Van Arensbergen, Daemen, Van der Meulen and Van den Besselaar, 2011; Probst, Lepori, De Filippo and Ingenhoff, 2011).

We elaborate an approach which identifies likely indicator needs from the policy process, explore examples of existing indicator use, and discuss the extent to which meeting each of our identified indicator needs is feasible. We conclude that decision-makers and indicator designers should work together to ensure that both new indicators and new approaches to mutual policy-learning about their use and utility are developed in parallel.

This paper suggests some new indicators related to firm 'additionality potential' by looking at the conditions enabling increasing returns of $R \& D$ to public subsidies; while it provides public agencies with a procedure to obtain an ex-ante synthetic measure of the (ex-post) R\&D additionality capacity of firms, rooted in the literature on credit-risk assessment.

We have continued our analyses of publication data of applicants for the Emmy NoetherProgramme (ENP) provided by the German Research Foundation. We compared the group of actual ENP applicants to a sample of potential applicants, which revealed a 'lack of low performers' among the actual ENP applicants. We conducted discriminant analyses to predict funding decisions on the basis of several bibliometric indicators.

The aim of this paper is to test the extent to which databases can be considered valuable sources for building positioning indicators to describe different profiles of university research activities, rather than their competitive position along the single dimensions of scientific production and academic reputation. Project results support the evidence that institutional databases are social constructs.

In this paper we present the findings of two case studies in fields where societal and scholarly output of research are highly intertwined (architecture and law). We analyze the nature of the two fields in terms of research areas and specific aspects of knowledge dynamics. This results in an approach and indicators for contextual research evaluation.

This paper presents an approach adopted in a project constructing an instrument for measuring research output in communication sciences in Switzerland in collaboration with the scientific community. The concept of profiles, allowing combination of output in different dimensions, is central and proved to be fruitful for the discussion of the instrument and its acceptance in the field. 
The journal of science, research, technology, innovation and policy

Science and Public Policy is a refereed, international journal on policies for science, technology and innovation, and on the implications of science, technology and innovation for other areas of policy. It covers all science, technology and innovation for other areas of policy. It covers all science and technology (basic, applied, high, low, or otherwise) and all countries. It is read in around 80 countries, in universities, government ministries and agencies, consultancies, industry and elsewhere.

\section{Editors}

Prof Susana Borrás, Center for

Business and Politics,

Copenhagen Business School,

Steen Blichersvej 22, 2000

Frederiksberg, Denmark; email:

scipol.cbp@cbs.dk

Prof Nicholas Vonortas, Center for International S\&T Policy, The George Washington University, 1957 E St NW, Suite 403, Washington, DC 20052, USA; email: vonortas@gwu.edu

Dr Caroline S Wagner, Center for International S\&T Policy, The George Washington University, 1957 E St NW, Suite 403, Washington, DC 20052, USA; email: cswagner@mac.com

\section{Book reviews editors}

Prof Cooper Langford,

Science, Technology \& Society Program, University of Calgary, Calgary, Alberta, Canada T2N 1N4; email: chlangfo@ ucalgary.ca

Dr Jakob Edler, Manchester Institute of Innovation Research (MIOIR), Manchester Business School, Manchester, M13 9PL, UK; email: Jakob.Edler@ mbs.ac.uk

\section{Publisher}

William Page, Beech Tree

Publishing, 10 Watford Close, Guildford, Surrey, GU1 2EP, UK

Tel: +44 1483824871

Fax: +441483 567497

Email: page@scipol.co.uk Website: www.scipol.co.uk with links to journal articles on Ingenta

\section{Production assistants Janet Hodgkinson

\section{Editorial advisory board}

Mario Albornoz, Centre for Studies of Science, Development and Higher Education, Buenos Aires, Argentina

Daniele Archibugi, a Director of the National Research Council, Italy

Anthony Arundel, UNU-MERIT, The Netherlands

Phillip Cooke, Advanced Studies, University of Cardiff, UK

Susan E Cozzens, School of Public Policy, Georgia Institute of Technology, USA

Paul Cunningham, MIOIR, Manchester Business School, UK

Charles Edquist, CIRCLE, Lund University, Sweden

Shu-lin Gu, Tsinghua University, Beijing, China

David Hart, Public Policy, George Mason University, USA

Ron Johnston, Executive Director, Australian Centre for Innovation and International Competitiveness, Sydney, Australia

Calestous Juma, Co-ordinator, UN Millennium Project Task Force on Science, Technology and Innovation, Kennedy School of Government, Harvard University, USA

Gary Kass, Parliamentary Office of S\&T, UK

Stefan Kuhlmann, School of Management and Governance, University of Twente, The Netherlands

Philippe Larédo, ENPC, Paris, France

Kong-Rae Lee, STEPI, South Korea

Rolf Lehming, Science

Resources Statistics, NSF, USA
Loet Leydesdorff, University of Amsterdam, The Netherlands

Angela Liberatore, European Commission, Brussels, Belgium

Elena Mirskaya, Russian

Academy of Sciences,

Moscow, Russia

Judith Mosoni-Fried, MTA

KSZI, Budapest, Hungary

Johann Mouton, CREST,

Stellenbosch University, South Africa

Richard R Nelson, Columbia University, USA

Helga Nowotny, Vice President, European Research Council

Hiroyuki Odagiri, Faculty of Social Innovation, Seijo University, Tokyo, Japan

Howard Rush, CENTRIM, Freeman Centre, Brighton, UK

Luis Sanz-Menéndez, Deputy Director-General, Ministry of S\&T, Spain

Judith Sutz, University

Research Council, Universidad de la República, Uruguay

Kevin Urama, African

Technology Policy Studies

Network, Kenya

Eric von Hippel, Head, Innovation and Entrepreneurship Group, MIT/Sloan School of Management, USA

Lea Velho, University of Campinas, Brazil

Bruno van Pottelsberghe, former Chief Economist, European Patents Office, now Free University of Brussels, Belgium

Subscription information, see inside back cover

Typeset mainly in Times by Hilary Soper, Beech Tree Publishing, and printed by EntaPrint, Cranleigh, Surrey, UK 


\begin{abstract}
Science and Public Policy is a refereed, international journal on policies for science, technology and
innovation, and on the implications of science, technology and innovation for other areas of policy. It covers
all science, technology and innovation for other areas of policy. It covers all science and techn, or otherwise) and
applied, high, low, or applied, high, low, or otherwise) and all countries. It is icy. It covers all science and technology (basic, government ministries and agencies, consultancies, industry and elsewhere.
\end{abstract}

\section{Subscription information,}

SPP is published monthly except for January and September.

\section{Open access}

All items in SPP become open access 24 months after publication on www.ingentaconnect.com/ content/beech/spp.

In the prices below, developing countries are all countries except those in the European Union, other Western Europe, or USA, Canada, Australia, New

Zealand, and Japan.

\section{Annual subscription (print and free online): $£ 385$, US $\$ 662$ or $€ 589$; to developing countries, $£ 278$, US $\$ 473$ or $€ 421$; personal subscriptions, any country, £89. US $\$ 152$ or $€ 136$.}

\section{Annual subscription (online only): orders for online-only originating in the UK, or from any organisation or person elsewhere in the EU not registered for VAT, should add $20.0 \%$ VAT (tax): $£ 336$, US $\$ 578$ or $€ 515$; to developing countries, $£ 242$, US $\$ 413$ or $€ 368$; personal subscriptions, any country, $£ 77$, US $\$ 136$ or $€ 122$.}

Introductory offer: six months for $£ 88$, US $\$ 136$ or $€ 126$, available to first-time subscribers.

Single copies (print): £39, US $\$ 68$ or $€ 60$ from Turpin Distribution (see below).

\section{Single copies or individual} papers (online only): all items are open access 24 months after publication. More recent whole issues or individual papers can be downloaded by subscribers or by using the pay-to-view option. The website is: www.ingentaconnect.com/ content/beech/spp.

\section{Included in print edition subscription price: air-speeded mail, online access through Ingenta and annual index.}

\section{Orders}

Subscriptions may start with any issue. Order print-plus-freeonline or online-only subscriptions from Science and Public Policy, Turpin Distribution Services, Stratton Business Park, Pegasus Drive, Biggleswade, Bedfordshire SG18 8QB, UK; email: custserv@turpin-distribution. com, or any subscription agent.

\section{Payment}

Payment may be made by Visa or MasterCard (using the pounds price), or by cheque in pounds sterling, US dollars or euros (payable to Beech Tree Publishing), or direct to the publisher's bank (ask for bank
details).

\section{Other currencies are} acceptable if accepted by our bank, but please add the equivalent of $£ 6$ or US $\$ 9$ per cheque to help cover extra
costs.

\section{Photocopies and copyright}

Copyright () Beech Tree Publishing 2011.

All Rights Reserved. No part of this publication may be reproduced, stored in a retrieval system, or transmitted, in any form or by any means, electronic, mechanical, photocopying, recording, scanning or otherwise, except as described below, without the permission in writing of the publisher. Copying of articles is not permitted except for personal and internal use, to the extent permitted by national copyright law, or under the terms of a licence issued by the national Reproduction Rights

Organisation (such as Copyright

Licensing Agency, 90 Tottenham Court Road, London W1T 4LP, Center Inc, 27 Congress Street, Salem, MA 01970, USA). Fees appear in the code at the foot of the first page of each article. Requests for permission for other kinds of copying, such as copying for general distribution, for advertising or promotional purposes, for creating new collective works, or for resale, and other enquiries, should be addressed to William Page at page@scipol.co.uk. 


\section{Some articles from Science and Public Policy}

\author{
With 60 to 70 papers a year, this short list may \\ miss those of most interest to you. Our Ingenta \\ website has them all, including pre-prints: \\ www.ingentaconnect.com/ content/beech/spp
}

Policies for co-ordination in the European Research Area: view from the social sciences and humanities, Nikos Kastrinos (European Commission), May 2010.

Are small, medium- and micro-sized enterprises engines of innovation? The reality in South Africa, Irma Booyens (Human Sciences Research Council, South Africa), February 2011.

Science-industry links in CEE and CIS: conventional policy wisdom facing reality, Slavo Radosevic (School of Slavonic and East European Studies, UK), August 2011.

EU-US differences in the size of R\&D intensive firms: do they explain the overall R\&D intensity gap?, Raquel Ortega-Argilés (Instituto Superior Técnico, Lisbon, Portugal) et al, July 2010.

Critical success factors for government-led foresight, Jonathan Calof (Telfer School of Management, Ottawa, Canada) et al, February 2010.

China's catching up in science and innovation: the experience of the Chinese Academy of Sciences, Xielin Liu (Chinese Academy of Sciences, China) et al, June 2010.
Assessing the impact of research on policy: a literature review, Annette Boaz (Kings College London, UK) et al, May 2009.

\section{some special issues}

The policy rationale for cross-sector research collaboration and contemporary consequences, guest edited by Tim Turpin and Manuel FernándezEsquinas, March 2011.

The emerging role of universities in socio-economic development through knowledge networking, guest edited by Mohammed Saad and Girma Zawdie, February 2011; Revised selected papers from the Triple Helix, Glasgow conference.

Interactions between public research organisations and industry in Latin America, guest edited by Gabriela Dutrénit and Valeria Arza, August 2010.

New insights on EU-US comparison of corporate R\&D, guest edited by Pietro Moncada-PaternòCastello, July 2010.

Impact and implications of future-oriented technology analysis for policy and decision-making, February 2010.

\section{Editors and advisors}

Dr Sybille Hinze Institute for Research Information and Quality, Bonn, Germany

Professor Nicholas Vonortas The George Washington University, USA.

Dr Caroline S Wagner Penn State University, USA. Professors Jakob Edler (MIOIR, Manchester, UK) and Cooper Langford (Calgary, Canada) and Merle Jacobs (Lund, Sweden), book review editors

Mario Albornoz Centre for Science, Development and Higher Education, Buenos Aires, Argentina

Daniele Archibugi a Director of the National Research Council, Italy

Anthony Arundel UNU-MERIT, Maastricht, Netherlands Phillip Cooke Advanced Studies, University of Cardiff, UK Susan E Cozzens Public Policy, Georgia Institute of Technology, Atlanta, USA

Paul Cunningham MIOIR, Manchester, UK Charles Edquist CIRCLE, Lund University, Sweden Shulin Gu Tsinghua University, Beijing, China David Hart Public Policy, George Mason University, USA Ron Johnston Executive Director, Australian Centre for Innovation and International Competitiveness, Sydney
Calestous Juma Co-ordinator, UN Millennium Task Force on ST\&I, and KSG, Harvard University, USA

Stefan Kuhlmann School of Management and Governance, University of Twente, The Netherlands Philippe Larédo ENPC, Paris, France

Kong-Rae Lee STEPI, South Korea

Rolf Lehming Science Resources Statistics, NSF, USA Loet Leydesdorff University of Amsterdam, Netherlands Angela Liberatore European Commission, Belgium Elena Mirskaya Russian Academy of Sciences, Moscow Judith Mosoni-Fried MTA KSZI, Budapest, Hungary Johann Mouton CREST, Stellenbosch, South Africa Richard R Nelson Columbia University, USA Helga Nowotny Vice President, European Research Council Hiroyuki Odagiri Economics, Seijo Univ, Japan Howard Rush CENTRIM, Freeman Centre, Brighton, UK Luis Sanz-Menéndez Director, Institute of Public Goods and Policies, Spain Judith Sutz University Research Council, Universidad de la República, Uruguay

Kevin Urama, African Tech Policy Studies Network, Kenya Bruno van Pottelsberghe formerly Chief Economist, European Patent Office, now Free University of Brussels Lea Velho University of Campinas, Brazil Eric von Hippel Head, Innovation and Entrepreneurship Group, MIT/Sloan School of Management, USA 


\section{ORDER FORM}

1

My name and address:

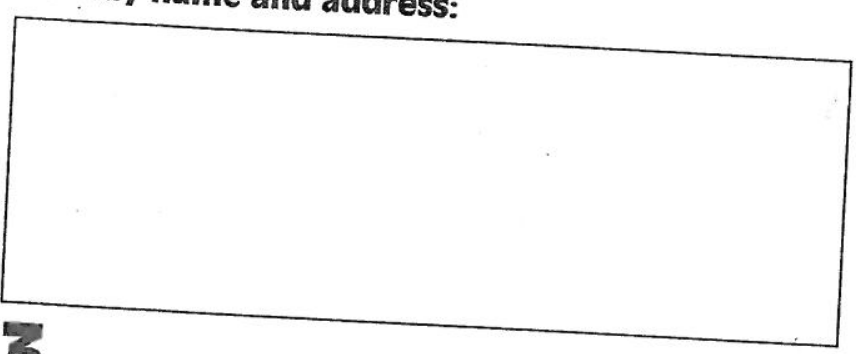

\section{Free issue:}

I am responding with a subscription order within two weeks of receiving this. So please send me a free copy of the special issue on:

Either Impacts of research

or Science parks

\section{I wish to subscribe to titles marked here:}

Orders for 'Online only' speeded mail. The online access is back to 1999; after 24 months, items are open access. from any organisation or person elsewhere in the EU not registered for VAT, should add $20 \%$ VAT (tax). (The in the UK, or
on our Print+online access.)

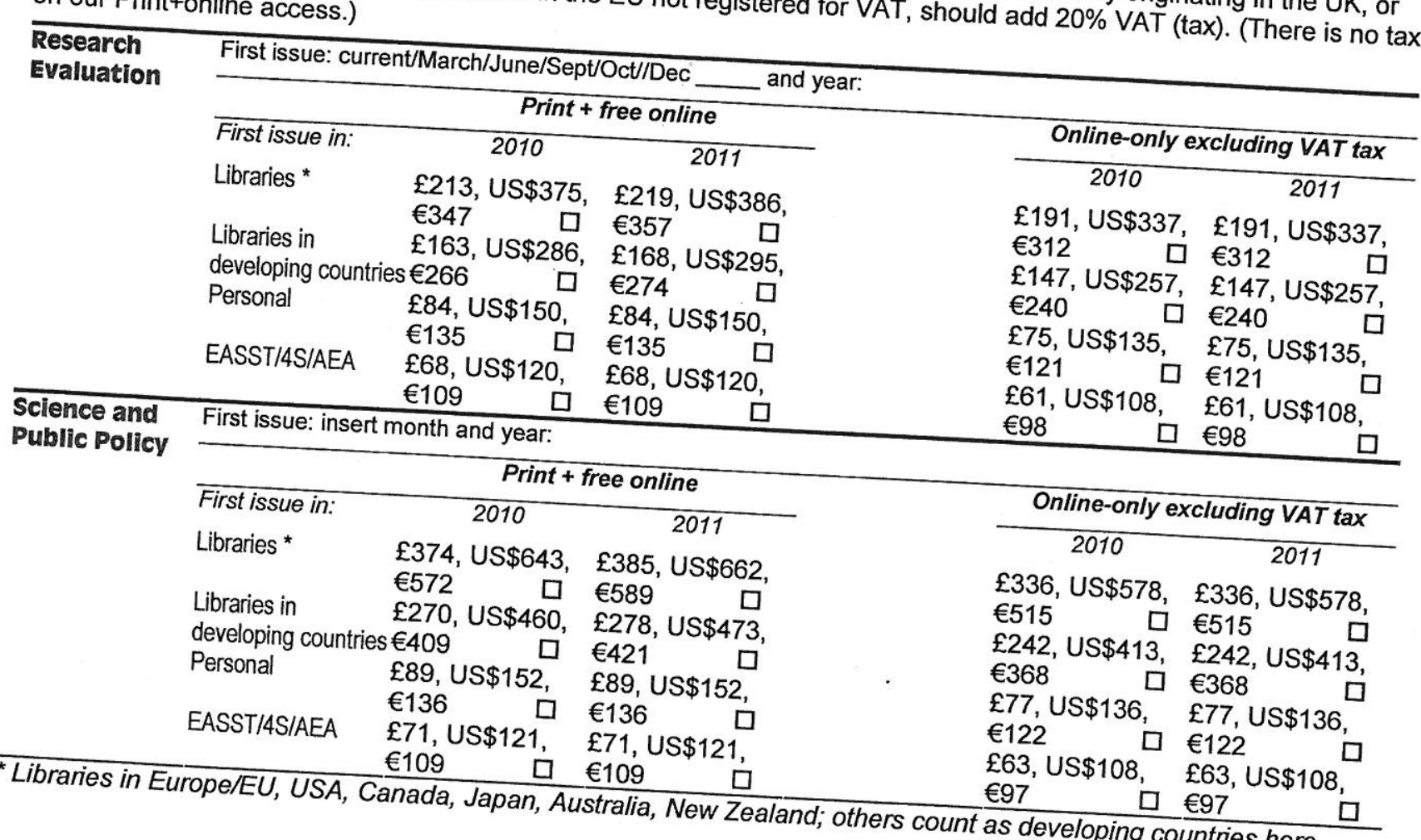

*Libranies in Europe/EU, USA, Canada, Japan, Australia, New Zealand; others count as

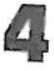

or

Payment I enclose $£ / U S \$ / € /$ other Cheques payable to Beech Tree Publishing
Visa/MasterCard card \#

incl 3 digit pin/CCV

or Bank Transfer send me details
or

or I enclose Unesco coupons for US\$

If in European Union (including UK):

what is your VAT tax number?

or

I don't have one

Ours is GB 3843019 54. (VAT on printed
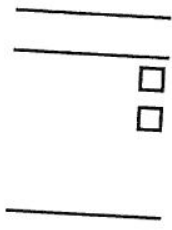

journals is $0 \%$, but we still have to ask you this!)

\section{Return this to:}

Beech Tree Publishing

10 Watford Close

Guildford GU1 2EP

Surrey, UK

Fax: +44 1483567497

Email: page@scipol.co.uk

Telephone: +44 1483824871

www.scipol.co.uk 